ARTICLE

\title{
Enacting Student Partnership as Though We Really Mean It: Some Freirean Principles for a Pedagogy of Partnership
}

\author{
*John Peters, Director of Teaching, Learning and Scholarship, Newman University, UK \\ Leoarna Mathias, Transition and Retention Programme Co-ordinator, Newman University, UK \\ Contact: $\underline{\text { J.Peters@staff.newman.ac.uk }}$
}

\begin{abstract}
The idea of student-staff partnership working is becoming increasingly popular in higher education. However, there is a risk that, as the idea spreads, the radical nature of partnership working can be diluted and domesticated by established power structures. This article explores the theoretical and practical implications of adopting approaches to partnership working informed by the ideas of Paulo Freire. This is partnership working with a political point-consciously seeking to resist the forces of neoliberalism and any attempts to domesticate partnership to that paradigm. Instead, a pedagogy of partnership, informed by Freire, is juxtaposed with neoliberal domesticated partnership, and six principles are offered for enacting partnership as though we really mean it.
\end{abstract}

\section{KEYWORDS}

students as partners, pedagogy of partnership, Paulo Freire, critical pedagogy, higher education

As the establishment and immediate popularity of this journal attests, student partnership has become a major developmental theme across and beyond English-speaking higher education (HE) (Bengtson et al., 2017; Cliffe et al., 2017; Frison \& Melacarne 2017; Mercer-Mapstone et al., 2017; Singh, 2018). Healey, Flint, and Harrington (2014) argue that "engaging students and staff effectively as partners in learning and teaching is arguably one of the most important issues facing HE in the twenty-first century," (p. 7) and, illustrating the growing quantity of work in the field, Healey's published bibliography on student partnership currently runs to over 40 pages (Healey, 2018).

Student partnership has often been promoted as a means of resisting the excesses of neoliberalism in HE (Dwyer, 2018; Matthews, 2017; Matthews et al., 2018a; Matthews et al., 2018b; NUS, 2012). A contested term in itself, "most scholars tend to agree that neoliberalism is broadly defined as the extension of competitive markets into all areas of life, including the 
economy, politics, and society" (Springer, Birch, \& MacLeavy, 2016, p. 2). Thus, neoliberalism argues that free markets "are the most moral and the most efficient means for producing and distributing goods and services" (Cahill, 2012, p. 111). It is a way of viewing the world that has come to underpin government policy in recent decades, for the UK and much of the western world, whatever political party has been in power. Its insidious nature is that it is a particular political position presented as apolitical common sense. Neoliberalism's domineering economic logic reduces $\mathrm{HE}$ to a commercial exchange between HE providers and student consumers, operating within a marketised system (Molesworth, Scullion, \& Nixon, 2010; Saunders, 2010). In this knowledge economy, universities, academics, students, and learning itself are all diminished where universities are competitive, managerial corporations; academics are employed training providers; students are passive, paying, individualised consumers; and learning is a packaged product (Molesworth, Scullion, \& Nixon, 2009; Naidoo \& Williams, 2015; Olssen \& Peters, 2005; Patrick, 2013). Notions of the university as a public good-a learning community making a valued contribution to society by providing time and space for academics to pursue knowledge for its own ends, while enabling students to grow and flourish intellectually, personally, and collectively-are lost in this reductive system (Collini, 2012).

Levy, Little, and Whelan argue that "the theme of staff-student partnerships reaches to the heart of debates about the values and role of the twenty-first-century university" (2011, $p$. 2). The National Union of Students in the UK proposed partnership as an antidote to both the traditional apprenticeship model and the increasingly dominant neoliberal consumerist model of HE (NUS, 2012). But they warn that it can only work if it truly entails "a meaningful dispersal of power" (2012, p. 8), echoing a core question posed by Levy and colleagues:

To what extent can power relations between staff and students be challenged and changed in $\mathrm{HE}$ given its prevailing ideological and structural characteristics, or are the barriers such that it is not possible to envisage wide-scale cultural change in the direction of genuine partnership? (Levy, Little, \& Whelan 2011, p. 12)

The implication is that genuine partnership requires more than consultation, involvement, or active participation of students as consumers; it demands a view of HE as a learning community in which students are equal participants, sharing leadership and authority with academics and HE managers (Peters, 2018). The student-partnership literature highlights barriers to enacting partnership in the face of established HE culture and customs, structures and practices, and identifies limitations to achieving genuine inclusivity (Bovill et al., 2016; Bovill \& Felten, 2016). We also need to be ever alive to the possibility that Students as Partners (SaP) "could be appropriated for neoliberal purposes" (Matthews et al., 2018a, p. 15). This paper, then, argues for the adoption of six principles for student-staff partnership, grounded in the critical pedagogy work of Paulo Freire, as a route to achieving genuine partnership and resisting such appropriation.

Truly enacting student partnership involves both a different view of HE and a shifting of power and, as such, constitutes a revolutionary attack on the established order of marketised HE practices. No wonder it is beset with obstacles. The threat is that, without a clear theoretical base and sense of its roots in critical pedagogy, students-as-partners practices could quickly 
succumb to the domestication that has often befallen other initiatives, such as student engagement and student voice research (Cook-Sather, 2007; Fielding, 2011; Bovill, 2013; Kahu, 2013; Seale et al., 2015; Peters 2018; Matthews et al., 2018b; Zepke, 2018). To better understand the radical principles of partnership and the challenges faced in bringing them to fruition, there is value in returning to the founding father's work of critical pedagogy and partnership in education: Paulo Freire. By theorising students-as-partners practices as a Freirean pedagogy of partnership, it becomes clear that there are indeed neoliberal, domesticating, and technocratic threats to meaningful partnership working.

\section{PAULO FREIRE AND STUDENT PARTNERSHIP}

Paulo Freire (1921-97) was a Brazilian educator, theorist, and activist. His championing of mass literacy campaigns in north-eastern Brazil, as a form of democratic education in action, led to his detention by the military government, followed by exile from Brazil for fifteen years, from 1964-79. He developed many of his ideas through conversation with contemporary theorists while in exile, before returning to serve as secretary of education for Sao Paulo and professor at the Pontifical Catholic University of Sao Paulo. An inspirational writer and educational activist, it is clearly impossible to do full justice, in the brief space here, to the nuanced ideas of someone who has been described as "perhaps the most influential thinker about education in the late twentieth century" (Smith, 1997, paragraph 1). His most influential early work, Pedagogy of the Oppressed $(1970,1996)$, critiques what he calls the "banking model" of education, in which students are characterised as the passive recipients of unproblematic knowledge content, delivered by knowledgeable teachers. Examples of such attitudes and practices he cites include the following:

The teacher teaches and the students are taught;

The teacher knows everything and the students know nothing;

The teacher talks and the students listen-meekly;

The teacher disciplines and the students are disciplined;

The teacher chooses the programme content, and the students (who were not consulted) adapt to it (1996, p. 54).

Further, students in this banking model are treated as "marginal" individuals who need to be "integrated" into society as it is, through pedagogic approaches that promote unquestioning acceptance and a "culture of silence" (Freire, 1996, p. 55). This de-humanises them, destroying hope and producing fatalistic acceptance of the way things are. In his later works, Freire expanded on the damage done by the banking model of education to our ability to be and become more human; to hope, dream, love, and grow.

A particularly insidious aspect of the banking model is the way it presents teaching as a politically neutral act. Thus, not only are students reduced by it, but the educational process is neutered. "Neoliberal doctrine seeks to limit education to technological practice. Currently, education is no longer understood as formative, but simply as training" (Freire, 2007, p. 4). And, again, 
The neoliberal point of view reinforces a pseudo-neutrality of the educational practice, reducing it to the transfer of information content to the learners, who are not required to apprehend it in order to learn it. Such "neutrality" serves as the foundation for reducing the education of a plumber to training in the techniques and procedures involved in wrench mastering (Freire, 1997, p. 46).

So, the teacher becomes a training provider, and the student is reduced to a trained wrench operative, with the skills to fulfil their role in the workforce; yet neither is engaged in an educational process that might lead them to question, challenge, or transform their world. Freire's alternative to the banking model should be immediately recognisable to studentpartnership practitioners, as it is grounded in learning with each other. It is an approach that fundamentally seeks to tear down the barrier between teacher and taught, draw on the experiences of tutors and students, and through "problem posing" engage all in mutual learning through meaningful discussion:

Through dialogue, the teacher-of-the-students and the students-of-the-teacher cease to exist and a new term emerges: teacher-student with student-teachers. The teacher is no longer merely the-one-who-teaches, but one who is himself taught in dialogue with the students, who in turn while being taught also teach. They become jointly responsible for a process in which all grow. (Freire, 1996, p. 61)

Thus, the educational process is not one of merely providing answers but is instead founded upon the asking of questions and the generation of curiosity. This is education as a profoundly political act-an act of liberation - an act of becoming collectively more conscious, through dialogue, of locating our critical awareness as a basis for collective transformative action. Such education seeks to reveal and question existing power structures, to hold them up as problems to be addressed, and to encourage the co-design of workable alternatives.

There is no such thing as a neutral education process. Education either functions as an instrument that is used to facilitate the integration of the younger generation into the logic of the present system and bring about conformity to it, or it becomes the "practice of freedom," the means by which men and women deal critically and creatively with reality and discover how to participate in the transformation of their world. (Freire, 1996, p. 16)

Freire highlighted tensions between a supposedly neutral banking model of education (rooted in neoliberalism with clear power hierarchies in operation, and seeking to domesticate the educational process and the participants in it) and education as learning together (from and with each other, as a means of questioning, challenging, and changing our world-education as liberation). Thus education, for Freire, does not separate learning about something from moving into doing something about it. Instead, the practice inherent in the educational process-problem posing and the co-development of solutions-means education combines 
learning and acting, a form of learning through action. As he articulates, "democracy is taught and learned through the practice of democracy" (1997, p. 91).

Through this vision of education as a democratising force, Freire is the central figure in the landscape of critical pedagogy (in which scholarship and advocacy on the part of oppressed groups are intertwined). This varied terrain is occupied by many whose work is at times shaped by a deep pessimism about the current state of the world in general and university pedagogic practice in particular. Freire, however, encourages us to join him in a hope-filled space, where a recognition of the unfinished nature of the human project (2014) allows us to remain optimistic for our students and ourselves: "How would it be possible for a consciously inconclusive being to become immersed in a permanent search without hope?" (1997, p. 93).

Freire inspired the academic bell hooks (1994); Henry Giroux, who drew heavily on Freire's work when he first conceptualised "critical pedagogy" (2009); and others to strive for democracy in the classroom and to resist the instrumentalised pedagogy that shapes much of what qualifies as teaching in our marketised HE institutions. Hughes (1998) describes her first reading of Freire in the following way: "It was and has continued to be the most inspirational reading I have ever done, both intellectually and in terms of my teaching practice" (p. 137). But Freire did not seek esteem for himself or his work, rather he saw his ideas as merely a step along the way to a future he was unlikely to witness (1997). In the project of student partnership as it is characterised here, we hope he would recognise a response to his call for reinvention-and not mere re-enactment-of his ideas (Freire, 1996). It would seem, then, that the students-as-partners movement, including its practices and conceptions, owe Freire a great deal, and that the enactment of a Freirean pedagogy of partnership lies well within our reach. However, it is important that we maintain awareness of the challenge we are undertaking and the powerfully domesticating forces operating against any form of educational practice which unsettles the established order.

\section{THE TENSION OF LIBERATION AND DOMESTICATION IN STUDENT PARTNERSHIP}

It is all too easy to see examples of domestication in students-as-partners practices across our current HE landscape. This can happen in many ways. First, if power relations remain distinctly uneven, partnership working becomes a sham, less a matter of collaboration and more a case of co-option. Second, and more insidiously, partnership can be reduced to a technocratic exercise in itself, shorn of democratic purpose. When this happens, it is possible to see partnership working deployed not as a means of challenge and transformation but as a means of control, subjugation, and othering. Furedi (2011) is right to warn us that "the conceptualisation of students as change agents may represent a form of unwitting manipulation of students to act in accordance with the logic of marketisation" (p. 3). Partnership can be framed in marketised ways - as a business-like, contractual relationship, or as a purely technocratic exercise. Unfortunately, Furedi's (2015) proposed answer to this risk undermines the democracy of the classroom that Freire advocates, falling back on claims for the primacy of academic authority whereby "students must trust in the authority of their teacher" (p. 166). White (2018) has also recently argued that students-as-partners practices can "damage the moral authority of the teacher" (p. 163) in that it gives power to students who have not yet finished their education. This contradicts Freire's teachings in two ways: by 
implying our students have nothing to teach us and by suggesting that their unfinished state means they are, thus, not ready to be decision-makers in their own education. Thankfully, Freirean partnership calls on us to be watchful of such potentially patronising understandings of $\mathrm{HE}$ - to see them as domesticating forces and to resist their rhetoric - instead maintaining our hope that democratic education through partnership is possible and achievable.

Partnership schemes that follow a business model are governed by contractual relationships. The university sets out its provision and requires students to accept the arrangement, including limits to their rights and an imposition of responsibilities. As such, students are expected to forgo key aspects of their agency in the relationship. This form of partnership - a joint but unequal agreement of services to be rendered and behavioural expectations to be met-denies all sense of human connection and growth (Cook-Sather, 2007). Commercialising the partnership model limits the human spirit and leads participants to acquiesce to certain conventions and limitations that remove the human element of hope and values. Such contracts work to limit the claims we can make on each other, a technical exercise that circumvents the messy authenticity of personally meaningful interaction (Felten, 2017). The contractual view of partnership has been explicitly rejected by even the Quality Assurance Agency for HE in the UK. Their UK Quality Code states the following:

Partnership working is based on the values of openness; trust and honesty; agreed shared goals and values; and regular communication between partners. It is not based on the legal concept of equal responsibility and liability; rather partnership work recognises that all members in partnership have legitimate, but different, perceptions and experiences. By working together to a common agreed purpose, steps can be taken that lead to enhancements for all concerned. $(2012$, p. 5)

Student partnership can also go the way of much work on student engagement and experience, becoming focused, not on creative and collaborative potential, but on deficit models to be addressed by technocratic means. Instead of recognising the complexity and potential of situated, growing, human relationships, work on student engagement (or partnership work carried out in this guise) can quickly be reduced to a means of addressing problems with student retention or endeavouring to counter the latest disappointing National Student Survey returns. The work of the UK's Higher Education Academy (HEA), now AdvanceHE, often falls into this trap. For example, the HEA (2016) urges HE institutions to acknowledge that "engaging students through partnership casts students as active participants in their learning" (p. 3). If we accept a constructivist view of learning, this is a meaningless statement. Students cannot be anything other than active participants in their own learning. This statement tends to be used when what is meant is that we want students to own what we wish them to learn, to engage in the ways we require, and to accept our teaching methods without challenge. Thus, student engagement and partnership working become strategic, institutional initiatives appropriated to neoliberal ends - a means of tying students into HE so that they complete their award, pay their fees, and provide feedback that satisfies metrics. The HEA's original overview model for SaP (Healey, Flint, \& Harrington, 2014, p. 25) fell into this technocratic trap of presenting partnership working as a system-a technocratic solution to 
issues of engagement, devoid of explicit values. This was corrected to some extent in the final version by the addition of underpinning values, drawn from Healey, Flint, and Harrington's companion publication and guidance, though these still lack clear radical purpose or a social justice dimension (Healey, Flint, \& Harrington, 2014, p. 14-15; HEA, 2016).

Writers from a number of perspectives have highlighted the particular dangers of education without explicit values and purpose. This warning underpins David Orr's plea that we think collectively about the purpose of education for sustainable development:

The truth is that without significant precautions, education can equip people merely to be more effective vandals of the earth. If one listens carefully, it may even be possible to hear the Creation groan every year in late May when another batch of smart, degreeholding, but ecologically illiterate, Homo sapiens who are eager to succeed are launched into the biosphere. (1994, p. 5)

A pedagogy of partnership requires that we remain hopeful and believe that an education based on questioning, values, and our collective humanity can equip us to transform our world for the better, not the worse. Thinking about science education in universities more generally, Maxwell (2014) has consistently urged us not to teach only knowledge, but also wisdom; to explain not just how we might do something, but to discuss why it might or might not be worthwhile and wise to do so.

Our resistance to the neoliberal trap of technocratic, supposed value- and purpose-free educational practice, needs to be grounded in a clear understanding of why the discourse of student engagement has become so problematic (Zepke, 2018). We know that "no practice is as vulnerable as education to political and scientific fashion" (Fairfield, 2009, p. 1), and the preoccupation within $\mathrm{HE}$ research around the nature of student engagement attests to this. Attempts to understand styles of engagement (Coates, 2007), perspectives on engagement (Kahu, 2013), and models of engagement (Trowler, 2010) all offer partial insight into the interplay between student and institution in the pursuit of learning. But, in focusing on either the individual attributes of the student or the mechanistic processes of the university, something can be lost. By implication, there is something reductively mathematical about the formulae offered to ensure that students succeed and institutions survive. In such explanations, the very idea of a meaningful pedagogical relationship is denied. Both Matthews (2016) and Zepke (2018) ask us to reject those understandings of student engagement and partnership that lack nuance and neglect the fundamental importance of human relations in educational collaboration. As White (2018) suggests, we must guard against such "non-moral, thin, functional conceptions of higher education" (p. 170) and their potential to "hollow out higher learning" (p. 171).

If Williams (2006) is correct, we, in this domesticating age, risk being witness to the "end of social hope" (p. 160) and of holding on to deficit views of the student in which opportunity and notions of quality are seen as proxies for access to a meaningful education (Antonucci, 2016; Kuh, 2009). A reading of Freire encourages us now, more than ever, to re-think how we address the student body (Neary, 2012). Dwyer (2018) argues that our scepticism about the current appropriation of partnership for neoliberal ends is well-founded, while Zepke (2018) 
asks us to re-engage with the moral purposes of education through the work we do to engage our students. Critical pedagogy, as an authentic tool with which we can tackle oppression, opens up before us, inviting us to instead see the "potential" (McLean, 2006) within each of us, and university life as a moment in which we can "prioritise life over profit, and autonomy over performativity" (Amsler, 2015, p. 18). Student partnership, as an expression of such values, can allow us to legitimately locate "collegiate and mutualist" practice (Callender \& Scott, 2013, p. 217), in even the most commercialised of educational spaces. As Arendt (2006) asserts,

Education is the point at which we decide whether we love the world enough to assume responsibility for it, and by the same token save it from that ruin which except for renewal, except for the coming of the new and the young, would be inevitable. (p. 193)

It is possible to contrast the language of technocratic partnership with that of Freirean ideas of partnership to elaborate the tension. See Table 1.

Table 1. The languages of partnership (Peters, 2018, p. 185)

\begin{tabular}{|l|l|}
\hline FREIREAN EDUCATIONAL & TECHNOCRATIC EDUCATIONAL \\
PARTNERSHIP & PARTNERSHIP \\
\hline - Romantic partnership & - Business partnership \\
- Love and hope & - Contract and charter \\
- Community action & - Stakeholder involvement \\
- Possible dreams & - Addressing shortcomings \\
- Social justice & - Employability \\
- Social benefit & - Individual benefit \\
- Community action & - Individual mobility \\
- Conscientizing & - Personal development \\
- Radicalisation & - Domestication \\
- Political & - Apolitical \\
- Holistic & - Technocratic \\
- Being more & - Empowerment \\
\hline
\end{tabular}

Many of the contrasts here should now need little explanation. The Freirean idea of partnership is human, emotional, and romantic, in the sense of investing the educational relationship with our hopes and dreams for each other. It emphasises the collegial and collective over the individual, seeking positive social change and benefit for all rather than social mobility and empowerment for particular individuals. This idea of individually and collectively "being more" is a richer vision of growth in consciousness and action; it entails coming together and taking power rather than waiting to be empowered by others. As Matthews and colleagues (2018a) suggest, students-as-partners, viewed in this way, is "dedicated to enriching each other as human beings and seek[s] to test what could be possible in society" (p. 10). 


\section{SIX PRINCIPLES OF FREIRIAN PARTNERSHIP}

A genuine idea of partnership should entail rejecting banking models of learning and teaching in favour of education as a transformational experience in which all grow. Along with Freire's work, the pedagogy of partnership should therefore draw on theories of change, transformation, and development, which emphasise hope, authenticity, and growth. For example, it is possible to combine the ambition of critical pedagogy with the positive collective growth of Appreciative Inquiry (Cooperrider \& Whitney, 2005) as a means of working with students to collectively "be more" (Kadi-Hanifi et al., 2014). While Appreciative Inquiry lacks the political and critical awareness of critical pedagogy, it provides a framework for hopeful collective development of a vision and collaborative design of a better way of being together (Cockell, McArthur-Blair, \& Schiller, 2013). It does this through emphasising dialogue and storytelling, focusing on what "brings life" to our collective endeavours, and taking the community through a four-stage framework of discovery, dreaming, design, and destiny or will to change (Ludema, Cooperrider, \& Barrett, 2001). Equally, living educational theory (Whitehead 1989) calls for authenticity in the way we live our values, and provides another way of thinking about how we might develop practice based on values of social justice and liberation, as long as we turn that analysis to collective, as well as personal, theory-in-action. In essence, we will each blend our own value-based pedagogic approach from a bespoke range of sources, but what is needed is to illustrate how these ideas might apply collectively to the pedagogy of partnership. Six guiding principles for this are offered below.

\section{Building from a shared hope and believing in our transformative potential}

The first step is a shared belief that together we can make a positive difference. As Freire (1997) puts it, "Hope is an ontological requirement for human beings" (p. 44). This is not passive wishing for the best but an active engagement, as Solnit (2017) says, "Hope is a belief that what we do might matter, an understanding that the future is not yet written. It's informed, astute open-mindedness about what can happen and what role we may play in it" (paragraph 4). Barack Obama built his campaign for presidential office around the importance of hope as a progressive ideal and a means of uniting people. This explicitly drew on the civil rights movement and was expressed on his arrival on the national stage at the 2004 Democratic Congress through the title of his second book, The Audacity of Hope, in the single-word campaign poster "hope," and finally, through his description of his victory as:

"The answer that led those who've been told for so long by so many to be cynical and fearful and doubtful about what we can achieve to put their hands on the arc of history and bend it once more toward the hope of a better day." (2004, 2008a, 2008b, paragraph 5)

This hope-filled approach-assuming that we care, that we want to make the world a better place, and that we can do so collectively, even if that may be in certain small or focused ways at first-should be axiomatic to HE. And yet, too often, such hope is overwhelmed by criticality and fatalistic cynicism, which denies the hope of a possible alternative and grudgingly accepts the dominance of neoliberal rhetoric while seeking individual advancement within it. 
The antidote is a position that sees academia as a vocation and a calling, across Boyer's four scholarships of discovery, integration, application and teaching and learning (1990), and equally, positions studying within $\mathrm{HE}$, not as an act of personal self-improvement, but of collective social action. It is Freire's emphasis on collective hope and transformation through democratic pedagogy that underpins partnership working. This is true, as with the other principles, not just for the social sciences, humanities, and arts-where participatory and discursive critical pedagogies are perhaps more common-but for all HE disciplines; science cannot be done without the hope that it will result in improved understanding and the possibility of transforming our world.

\section{Asking how we can collectively be more and establishing a shared dream of transformation}

Being more is preferred here to the competitive being the best or feeling empowered, because it indicates human growth and presence without competitive edge or necessarily giving power to, or taking power from, others (Freire 2007). It means creating opportunities and space to explore what we all hope can be gained during our time in HE. Whether this is about sharing our dreams, helping each other to achieve our academic and professional goals, setting ourselves more challenging missions to contribute to human knowledge, or making a difference in our communities, this is not a focus on fitting in with the way things are, but about making a better future. Again, this requires a rejection of the prevalent cynicism of critique and the maintenance of hope. Freire (2014) begins Pedagogy of Hope:

We are surrounded by a pragmatic discourse that would have us adapt to the facts of reality. Dreams, and utopia, are called not only useless, but positively impeding. (After all, they are an intrinsic part of any educational practice with the power to unmask the dominant lies.) (p. 1)

As Levitas (2007) points out, "What matters is that the utopian experiment disrupts the taken-for-granted nature of the present" (p. 53). Thus, we are called upon to focus on formulating our ethos and allowing this to guide our actions (Hodgson, Vlieghe, \& Zamojski, 2018). There is a reason why Martin Luther King Jr.'s "I have a dream" speech still echoes through to the present; there is an educational power in dreaming.

\section{Promoting respectful dialogue}

Such approaches cannot avoid discussion of our values and intentions. "Only dialogue, which requires critical thinking, is also capable of generating critical thinking" (Freire, 1996, p. 73). Space must be created to hear under-represented voices and share experiences.

Partnership working is underpinned by the recognition that our diversity is a strength, bringing together a vast range of experience, knowledge, and understanding, which we can learn from and build upon. To do this, we need to listen with open hearts and humble mindsets, before leaping to debate and critique. This applies as much across a humanities seminar group as it does across major international science collaborations. It can also move beyond the usual academic-student dichotomy to include advisers, professional and support staff, practitioners, 
and all community members in learning and working together in what Freire (1996) called "culture circles" (p. 101). This often requires acceptance, allowing ourselves to hear hard and unpalatable truths, truths that question whether we are living our values-in-action and ask us to recognise how we often oppress or essentialise our students (Cook-Sather, 2007). Such genuine listening is an integral part of movements to decolonise the curriculum across all subject areas and requires us to acknowledge that we have been complicit in oppression (Le Grange, 2016). This is the democratic, intergenerational learning, which Fielding (2011) presents as the pinnacle of student voice work, "a pedagogy of relationships and listening" (Fielding \& Moss, 2011, p. 15).

\section{Engaging in co-investigation, shared reflection, problem posing, curiosity, rational exploration, and creativity}

The range of specific learning and teaching methods that could form part of the pedagogy of partnership is vast; examples include research-based teaching, project working, inquiry-based learning, and peer assessment. Their uniting features are that they should be authentic, meaningful to those involved, active, and collaborative. Students and tutors do not have to work together in groups at all times, but there must be a sense of collective purpose and of pooling ideas. Critical curiosity can take many forms, but it starts by questioning what is, why it is so, and whether it must be that way. It requires us to challenge ideas of common sense, to hold our traditions and assumptions up for question, and to query expectations of progress. It is generative of new ideas, explanations, and possibilities. Fundamentally, it aims to be democratic, inviting contributions from all and valuing all those contributions. It stands against the continued dominance of lecturing as a perceived means of conveying accepted knowledge to passive, consuming students. Thompson (1991) provides an example of the humility needed to hear under-represented voices and the openness to question the arc of progress. In his now-famous foreword to The Making of the English Working Class, he sought "to rescue the poor stockinger, the Luddite cropper, the 'obsolete' hand-loom weaver, the 'Utopian' artisan, and even the deluded follower of Joanna Southcott, from the enormous condescension of posterity." But this questioning and problem posing was not limited to the study of the past, or to the classroom; it included acknowledging the contribution made by his students to that great book. He states, "I have...learned a great deal from members of my tutorial classes" (1991, p. 13) and elsewhere argues, "All education which is worth the name involves a relationship of mutuality, a dialectic." (1968, p. 16) He further joined with his students to occupy and critique his own university for its increasing commercialisation (Thompson, 2014).

\section{Seeking the co-construction of solutions aimed at a better way of being together}

Addressing authentic issues has the potential to produce meaningful changes that promote social justice and improve our collective lives. A Freirean pedagogy of partnership will not just deliver particular outcomes or improvements in understanding, but is also focused on social benefits, promoting a greater understanding of how we can work together to tackle greater challenges. It is about caring about, and for, each other and increasing our capacity to collaborate effectively. Whether they are aimed at decolonising the curriculum, opening up 
access to support for previously under-represented groups, or engaging in service learning -as examples of partnership working have done at our own institution - such principled approaches to student-staff partnerships have the capacity to contribute to the life of the institution, those who study and work within it, and the communities, both local and global, with which it engages. Campbell and Lassiter (2010) provided an example of this with The Other Side of Middletown project. Beyond the project itself, they explored "the relationship of collaborative ethnography to modes of collaborative engagement and, especially, collaborative pedagogiesprocesses by which faculty, students, and members of local communities work as an enlarged community of co-learners, co-researchers, and, ultimately, co-citizens" (p. 370). Authentic partnership means doing something, changing something, acting-as well as critiquing.

\section{An on-going transformative and collaborative process of being and becoming}

By its nature, the pedagogy of partnership cannot be contained in formal programmes or teaching sessions. It will spill out into other aspects of study and life. For example, working in partnership with students on Appreciative Inquiries changed the tone of student engagement work more broadly across one institute of education (Kadi-Hanifi et al., 2014). Two participants in that project observed that "confidence and ability have been instilled in us since day one of the project...the positive outcomes for us personally are evident in our academic achievements and belief in our own potential" (Tutton \& Snell, 2013). Partnership is enduring and unconfined and, once experienced, there is no going back. As one student partner at our own institution explained, "I have learnt that I value who I am, where I have emerged from and what I represent for my community... [I have] learnt what [my] voice can achieve [and do] not want to go back into the silent shadows or [my] previous existence" (Locke in Lea, 2015, p. 178).

\section{CONCLUSIONS}

The implications of adopting a Freirean approach to students-as-partners in our role as academics are manifold. This is not about adopting a few new tricks, techniques, or strategies, but instead entails a personal, philosophical, and political commitment. It is to move consciously away from being the sage on the stage (McWilliams, 2009), towards a pedagogy in which "you don't try to impress the students with oratory, you try to challenge them, get them to question you" (Chomsky in Farndale, 2010, paragraph 10). For both students and staff, authentic partnership working demands genuine inward reflection and outward dedication to collective effort. As Angela Davis (2013) reminds us, "You have to act as if it were possible to radically transform the world. And you have to do it all the time" (p.u.). Authentic partnership requires the maintenance of hope that we can and will collectively challenge the dominance of neoliberal ideas in HE. We have to stay romantically attached to the certain belief that education is a profoundly subversive and transformative act of "renewing our 'unfinished selves' as we teach and assist students in becoming active, democratic citizens, capable and confident of transforming their world" (Peters, 2018, p. 187). 


\section{ACKNOWLEDGEMENTS}

This article is based on "The pedagogy of partnership: Six principles for action" by John Peters, first published in Educational Developments, 17.4, 8-9. The authors would like to thank the Staff and Educational Development Association for permission to develop it for this publication.

\section{NOTE ON CONTRIBUTORS}

John Peters is Professor of Higher Education Practice and Director of Learning, Teaching and Scholarship at Newman University, Birmingham, UK, where he leads their student-staff partnership project scheme.

Leoarna Mathias is Transition and Retention Programme Co-ordinator at Newman University, Birmingham, UK, and has been a staff partner on a number of student-staff partnership projects.

\section{REFERENCES}

Amsler, S. (2015). The education of radical democracy. London: Routledge.

Antonucci, L. (2016). Student lives in crisis: deepening inequality in times of austerity. Bristol: Policy Press.

Arendt, H. (2006). Between past and future: eight exercises in political thought. London: Penguin.

hooks, b. (1994). Teaching to transgress: education as the practice of freedom. London: Routledge.

Bengtson, C., Ahlkvist, M., Ekeroth, W., Nilsen-Moe, A., Proos Vedin, N., Rodiuchkina, K., Ye, S., \& Lundberg, M. (2017). Working as partners: course development by a studentteacher team. International Journal for the Scholarship of Teaching and Learning, 11(2), 1-9. Retrieved from: https://doi.org/10.20429/ijsotl.2017.110206

Bovill, C. (2013). Students and staff co-creating curricula-a new trend or an old idea we never got round to implementing? In C. Rust, Improving student learning through research and scholarship: 20 years of ISL. (pp. 96-108) Oxford: OCSLD.

Bovill, C., Cook-Sather, A., Felten, P., Millard, L., \& Moore-Cherry, N. (2016). Addressing potential challenges in co-creating learning and teaching: overcoming resistance, navigating institutional norms and ensuring inclusivity in student-staff partnerships. Higher Education, 71(2), 195-208. Retrieved from: https://doi:10.1007/s10734-0159896-4

Bovill, C., \& Felten, P. (2016). Cultivating student-staff partnerships through research and practice. International Journal for Academic Development, 21(1), 1-3. Retrieved from: https://doi.org/10.1080/1360144X.2016.1124965

Boyer, E. L. (1990). Scholarship reconsidered: priorities of the professoriate. New Jersey: Princeton University Press. 
Cahill, D. (2012). The embedded neoliberal economy. In D. Cahill, L. Edwards, \& F. Stilwell. Neoliberalism: beyond the free market. (pp. 110-27) Cheltenham, UK: Edward Elgar.

Callender, C., \& Scott, P. (2013) 'Browne and Beyond: Modernizing English Higher Education'. Bedford Way Papers. London: IOE Press Retrieved from: http://discovery.ucl.ac.uk/10017608

Campbell, E., \& Lassiter, L. (2010). From collaborative ethnography to collaborative pedagogy: Reflections on the other side of Middletown project and community-university research partnerships. Anthropology \& Education Quarterly, 41(4), 370-385. Retrieved from: https://doi.org/10.1111/j.1548-1492.2010.01098.x

Cliffe, A., Cook-Sather, A., Healey, M., Healey, R., Marquis, E., Matthews, K. E., MercerMapstone, L., Ntem, A., Puri, V., \& Woolmer, C. (2017). Launching a journal about and through Students as Partners. International Journal for Students as Partners, 1(1) 1-9 Retrieved from: https://doi.org/10.15173/ijsap.v1i1.3194

Coates, H. (2007). A model of online and general campus-based student engagement. Assessment and Evaluation in Higher Education, 32(2), 121-141. Retrieved from: https://doi.org/10.1080/02602930600801878

Cockell, J. McArthur-Blair, J., with Schiller, M. (2013). Appreciative inquiry in Higher Education: a transformative force. London: Wiley.

Collini, S. (2012). What are universities for? London: Penguin.

Cook-Sather, A. (2007). Resisting the impositional potential of student voice work: Lessons for liberatory educational research from poststructuralist feminist critiques of critical pedagogy. Discourse: Studies in the Cultural Politics of Education, 28(3), 389-403. Retrieved from: https://doi.org/10.1080/01596300701458962

Cooperrider, D., \& Whitney, D. (2005). Appreciative inquiry: A positive revolution in change. Oakland: Berrett-Koehler Publishers.

Davis, A. (2013, February 13). A lecture delivered at Southern Illinois University, Carbondale [Video file]. Retrieved from: https://www.youtube.com/watch?v=6s8QCucFADc

Dwyer, A. (2018). Toward the formation of genuine partnership spaces. International Journal for Students as Partners, 2(1), 11-15. Retrieved from: https://doi.org/10.15173/ijsap.v2i1.3503

Farndale, N. (2010, July 6). Noam Chomsky interview. The Telegraph. Retrieved from: https://www.telegraph.co.uk/culture/books/7865508/Noam-Chomsky-interview.html

Fairfield, P. (2009). Education after Dewey. London: Bloomsbury.

Felten, P. (2017). Emotions and partnerships. International Journal for Students as Partners, 1(2), 1-5. Retrieved from: https://doi.org/10.15173/ijsap.v1i2.3070

Furedi, F. (2011). Introduction. In M. Molesworth, E. Nixon, \& R. Scullion. The marketization of Higher Education and the student as consumer. London: Routledge. (pp.1-8)

Furedi, F. (2015). Academic authority in Higher Education. In J. Lea. Enhancing learning and teaching in Higher Education. Maidenhead, UK: Open University Press. (pp.165-167)

Fielding, M. (2011). Patterns of partnership: Student voice, intergenerational learning and democratic fellowship. In N. Mockler, \& J. Sachs. Rethinking educational practice through reflexive inquiry. (pp. 61-75) Dordrecht: Springer. 
Fielding, M., \& Moss, P. (2011). Radical education and the common school: A democratic alternative. London: Routledge.

Freire, P. (1996). Pedagogy of the oppressed (revised). London: Penguin.

Freire, P. (1997). Pedagogy of the heart. New York: Continuum.

Freire, P. (2007). Daring to dream: Toward a pedagogy of the unfinished. Boulder, USA: Paradigm Publishers.

Freire, P. (2014). Pedagogy of hope. London: Bloomsbury.

Frison, D., \& Melacarne, C. (2017). Students-faculty partnership in Italy: Approaches, practices, and perspectives. Teaching and Learning Together in Higher Education, 20 (Special Issue). Retrieved from: https://repository.brynmawr.edu/tlthe/vol1/iss20/

Giroux, H. (2009). Critical theory and educational practice. In A. Darder, M. Baltodano, \& R. Torres. (Ed) The critical pedagogy reader. (pp. 27-51) New York: Routledge.

Healey, M. (2018). Students as Partners and Change Agents: A selected bibliography. Retrieved from: www.mickhealey.co.uk/resources

Healey, M., Flint, A., \& Harrington, K. (2014). Developing Students as Partners in learning and teaching in Higher Education. York: Higher Education Academy.

Higher Education Academy. (2016). Framework for student engagement through partnership. York: HEA. Retrieved from

https://www.heacademy.ac.uk/system/files/downloads/student-enagagementthrough-partnership.pdf

Hodgson, N., Vlieghe, J., \& Zamojski, P. (2018) Education and the love for the world: articulating a post-critical educational philosophy. Foro de Educación, 16(24), 7-20. Retrieved from: http://dx.doi.org/10.14516/fde.576

Hughes, K. (1998). Liberation? Domestication? Freire and feminism in the university. Convergence, 31(1), 137-146.

Kadi-Hanifi, K., Dagman, O., Peters, J., Snell, E., Tutton, C., \& Wright, T. (2014). Engaging students and staff with educational development through appreciative inquiry. Innovations in Education and Teaching International, 51(6), 584-594. Retrived from: https://doi.org/10.1080/14703297.2013.796719

Kahu, E. (2013). Framing student engagement in higher education. Studies in Higher Education, 38(5), 758-773. Retrieved from: https://doi.org/10.1080/03075079.2011.598505

Kehler, A., Verwoord, R., \& Smith, H. (2017). We are the process: Reflections on the underestimation of power in Students as Partners in practice. International Journal for Students as Partners, 1(1), 1-15. https://doi.org/10.15173/ijsap.v1i1.3176

Kuh, G. D. (2009). The national survey of student engagement: Conceptual and empirical foundations. New Directions for Institutional Research, 141, 5-20. Retrieved from: https://doi.org/10.1002/ir.283

Le Grange, L. (2016). Decolonising the university curriculum. South African Journal of Higher Education, 30(2), 1-12. Retrieved from: https://doi:10.20853/30-2-709

Levitas, R. (2007). The imaginary reconstitution of society: Utopia as a method. In T. Moylan, and R. Baccolini. Utopia method vision: The use value of social dreaming. (pp. 47-68) Bern, Switzerland: Peter Lang. 
Levy, P., Little, S., \& Whelan, N. (2011). Perspectives on staff-student partnership in learning, research and educational enhancement. In S. Little (Ed.). Staff-student partnerships in higher education (pp. 1-15) London: Continuum.

Locke, D. (2015). On Higher Education as transformative. In J. Lea. Enhancing learning and teaching in higher education (p. 178) Maidenhead: Open University Press.

Ludema, J., Cooperrider, D., \& Barrett, F. (2001). Appreciative inquiry: The power of the unconditional positive question. In P. Reason \& H. Bradbury. Handbook of action research. (pp. 189-199) London: Sage.

McLean, M. (2006). Pedagogy and the university: Critical theory and practice. London: Bloomsbury.

McWilliams, E. (2009). Teaching for creativity: from sage to guide to meddler. Asia Pacific Journal of Education, 29(3), 281-293. Retrieved from: https://doi.org/10.1080/02188790903092787

Matthews, K. E. (2016). Students as Partners as the future of student engagement. Student Engagement in Higher Education Journal, 1(1), 1-5. Retrieved from: https://journals.gre.ac.uk/index.php/raise

Matthews, K. E. (2017). Five propositions for genuine Students as Partners practice. International Journal for Students as Partners, 1(2) p.1-9. Retrieved from https://doi.org/10.15173/ijsap.v1i2.3315

Matthews, K. E., Dwyer, A., Hine, L., \& Turner, J. (2018a). Conceptions of Students as Partners. Higher Education, 1-15. Retrieved from: https://doi.org/10.1007/s10734-018-0257-y

Matthews, K. E., Dwyer, A., Russell, S., \& Enright, E. (2018b). It is a complicated thing: Leaders' conceptions of Students as Partners in the neoliberal university. Studies in Higher Education. Retrieved from: https://doi:10.1080/03075079.2018.1482268

Maxwell, N. (2014). How universities can help create a wiser world: the urgent need for an academic revolution. Exeter, UK: Imprint Academic.

Mercer-Mapstone, L., Dvorakova, S. L., Matthews, K. E., Abbot, S., Cheng, B., Felten, P., Knorr, K., Marquis, E., Shammas, R., \& Swaim, K. (2017). A systematic literature review of Students as Partners in higher education. International Journal for Students as Partners, 1(1), 1-23. Retrieved from: https://doi.org/10.15173/ijsap.v1i1.3119

Molesworth, M., Nixon, E., \& Scullion, R. (2009). Having, being and higher education: The marketisation of the university and the transformation of the student into consumer. Teaching in Higher Education, 14(3), 277-287. Retrieved from: https://doi.org/10.1080/13562510902898841

Molesworth, M., Scullion, R., \& Nixon, E. (2010). The marketisation of higher education and the student as consumer. London: Routledge.

Naidoo, R., \& Williams, J. (2015). The neoliberal regime in English higher education: Charters, consumers and the erosion of the public good. Critical Studies in Education, 56(2), 208223. https://doi.org/10.1080/17508487.2014.939098

Neary, M. (2012). Beyond teaching public: The university as a form of social knowing. In $\mathrm{H}$. Stevenson, L. Bell, \& M. Neary (Ed.). Towards teaching in public: Reshaping the modern university. (pp. 148-164) London: Continuum. 
NUS. (2012). A Manifesto for Partnership. Retrieved from: https://www.nus.org.uk/PageFiles/12238/A\%20Manifesto\%20for\%20Partnership.pdf

Obama, B. (2004, July 27). Keynote Address 2004 Democratic National Convention, Fleet Center, Boston, MA. Retrieved from: http://p2004.org/demconv04/obama072704spt.html

Obama, B. (2008a). The Audacity of Hope. Canongate Books: Edinburgh.

Obama, B. (2008b, November 4). Election Night Victory Speech, Grant Park, Illinois. Retrieved from: http://obamaspeeches.com/E11-Barack-Obama-Election-Night-Victory-SpeechGrant-Park-Illinois-November-4-2008.htm

Olssen, M., \& Peters, M. A. (2005). Neoliberalism, higher education and the knowledge economy: From the free market to knowledge capitalism. Journal of Education Policy, 20(3), 313-345. Retrieved from: https://doi.org/10.1080/02680930500108718

O'Neill, G., \& McMahon, S. (2012). Giving student groups a stronger voice: Using participatory research and action (PRA) to initiate change to a curriculum. Innovations in Education and Teaching International, 49(2), 161-171. Retrieved from: https://doi.org/10.1080/14703297.2012.677656

Orr, D. (1994). Earth in mind: On education, environment and the human prospect. Washington, DC: Island Press.

Patrick, F. (2013). Neoliberalism, the knowledge economy, and the learner: Challenging the inevitability of the commodified self as an outcome of education. ISRN Education, 2013. Retrieved from: http://dx.doi.org/10.1155/2013/108705

Peters, J. (2018). The pedagogies of partnership: From Blair to Freire? In A. Melling and R. Pilkington. Paulo Freire and transformative education (pp. 175-189). London: Palgrave Macmillan.

Peters, J. (2016). The pedagogy of partnership: Six principles for action. Educational Developments, 17(4), 8-9 [December]. Retrieved from: https://www.seda.ac.uk/pastissues/17.4

Quality Assurance Agency. (2012). UK Quality Code for Higher Education: Part B, Assuring and enhancing academic quality; chapter 5: Student engagement. Retrieved from: https://www.qaa.ac.uk/quality-code/the-existing-uk-quality-code/part-b-assuring-andenhancing-academic-quality

Saunders, D. B. (2010). Neoliberal ideology and public higher education in the United States. Journal for Critical Education Policy Studies, 8(1), 41-77. Retrieved from: http://www.jceps.com/archives/626

Saunders, D. B. (2015). They do not buy it: Exploring the extent to which entering first-year students view themselves as customers. Journal of Marketing for Higher Education, 25(1), 5-28. Retrieved from: https://doi.org/10.1080/08841241.2014.969798

Seale, J., Gibson, S., Haynes, J., \& Potter, A. (2015). Power and resistance: Reflections on the rhetoric and reality of using participatory methods to promote student voice and engagement in higher education. Journal of Further and Higher Education, 39(4), 534553. Retrieved from: https://doi.org/10.1080/0309877X.2014.938264

Singh, J. K. N. (2018). Evidence and benefits of postgraduate international students-staff members partnership in extra-curricular activities: A Malaysian perspective. Higher 
Education Research \& Development. Retrieved from: https://doi:10.1080/07294360.2018.1436527

Smith, M. K. (1997, 2002). Paulo Freire and informal education. The Encyclopaedia of Informal Education. Retrieved from: http://infed.org/mobi/paulo-freire-dialogue-praxis-andeducation/

Solnit, R. (2017) Protest and persist: Why giving up hope is not an option. The Guardian, $13^{\text {th }}$ March 2017. Retrieved from: https://www.theguardian.com/world/2017/mar/13/protest-persist-hope-trumpactivism-anti-nuclear-movement

Springer, S., Birch, K., \& MacLeavy, J. (2016). The handbook of neoliberalism. London: Routledge.

Thompson, E. P. (1968). Education and Experience. Fifth Mansbridge Memorial Lecture. Leeds: Leeds University Press.

Thompson, E. P. (2014). Warwick university ltd. Spokesman Books.

Thompson, E. P. (1991). The making of the English working class. London: Penguin.

Trowler, V. (2010) Student Engagement Literature Review York: HEA Retrieved from: https://www.heacademy.ac.uk/system/files/studentengagementliteraturereview 1.pd $\underline{f}$

Tutton, C. \& Snell, E. (2013). Student researchers as educational developers: Our journey. Educational Developments, 14(1), 11-13. Retrieved from: https://www.seda.ac.uk/past-issues/14.1

White, M. (2018). Student partnership, trust and authority in universities. Educational Philosophy and Theory, 50(2), 163-173. Retrieved from: https://doi.org/10.1080/00131857.2016.1153451

Whitehead, J. (1989). Creating a living educational theory from questions of the kind, 'How do I improve my practice?' Cambridge Journal of Education, 19(1), 41-52.

Williams, J. (2006). The pedagogy of debt. College Literature, 33(4), 155-169. Retrieved from http://www.jstor.org/stable/25115391

Zepke, N. (2018). Student engagement in neo-liberal times: What is missing? Higher Education Research and Development, 37(2), 433-446.

https://doi.org/10.1080/07294360.2017.1370440 